\title{
Phytochemical screening and antimicrobial efficacy of ethanolic Extracts from Moringa pterygosperma Gaertn
}

\author{
Dr. Rohit kumar Bargah \\ Department of Chemistry, Govt. S.P.M. College Sitapur Distt .Surguja (C. G.) India 497111
}

\begin{abstract}
The antibacterial activity and phytochemical properties of Moringa pterygosperma, Gaertn. Was investigated the result obtained showed that the ethanolic extracts from the flower part were active against both gram negative and gram positive bacteria. The qualitative phytochemical screening of these flowers parts indicated the presence of flavonoids, alkaloids, steroids, carbohydrate, glycoside, protein and amino acid etc. in the ethanolic extracts. The ethanolic extracts showed antibacterial activity was obtained from the against, Micrococcus luteus, Staphylococcus aureus, Bacillus subtilis, Escherichia coli, Pseudomonas aeruginosa and Vibrio cholera all gram positive and gram negative bacteria is maximum zone of inhibition. The susceptibly of the different strain of flowers ethanolic extracts investigated. This attest to the fact that Moringa pterygosperma contains bioactive compounds of potentially therapeutic and prophylactic significance and thus cold by a promising candidate for drug development. This study indicated the potential efficacy of the Moringa pterygosperma in the treatment of infections caused by the test organisms'. Further research on this charismatic healer may lead to the development of novel agents for various diseases and establish its pharmaceutical knack in modern medicine.
\end{abstract}

Keyword: antibacterial activity, ethanolic extract, Moringa pterygosperma, phytochemical screening,

\section{Introduction}

In Indian system of medicine a large number of drugs of either herbal or mineral origin have been adrocated for various type of disease. Herbal medicines are still widely used in many parts of the world especially in areas where people do not have access to modern medicine $(\mathbf{1 , 2})$ plants with their wide variety of chemical constituent offer a promising source of new anti microbial agents with general as well as specific anti microbial activity $(\mathbf{3}, \mathbf{4 , 5})$. There are general reports on the presence of anti microbial compounds in various plant parts like flower, stem bark, fruits and root (6). A number of plants have been screened for their antibacterial properties especially to the flower.

Moringa pterygosperma Gaertn. is one of the best known widely distributed and grown species of a monogeneric family Moringaceae(7).Moringa pterygosperma is a small fast growing evergreen tree that usually grows up to $12 \mathrm{~m}$ in its height, open crown of drooping fragile branches, feathery foliage of trip innate leaves and thick corky, whitish bark (8).The plant is highly valuated since almost every part of the plant viz. leaves, roots; barks, fruits, flowers etc. are used as highly nutritional and medicinal properties (9). In addition the plant has been reposted to possess antibacterial properties and this explains the reasons for its wide use in the treatment of human diseases $(\mathbf{1 0}, \mathbf{1 1})$.

Moringa pterygosperma is used as drug many ayurvedic practitioners for the treatment of asthma and evaluate the anthelmintic activity of methanolic extract of Moringa pterygosperma was also noted(12).The Moringa plant provides a rich and rare combination of flavonoids, steroids, saponins and many other phytochemicals. It is a very important for medicinal value various parts of the plant such as the leaves, stem bark, seed, fruits, flowers act as cardiac and circulatory stimulants, antitumor, antipyretic, anti-inflammatory, anti ulcer $(\mathbf{1 3}, \mathbf{1 4})$.Other important medicinal properties of the plant include anti spasmodic (10), anti oxidant (15), anti hypertensive (16), anti diabetic (17) and anti bacterial (18) and anti fungal activities $(\mathbf{1 9}, \mathbf{2 0})$.

\section{Materials and methods}

1.1 Collection of plant material: The flowers of Moringa pterygosperma Gaertn were collected from local areas of Deveri khurd Bilaspur (C.G.) in Nov-Dec 2013 and authenticated by Prof. .N. K .Singh, Department of Botany,Govt. E.R.R.Science P.G.College Bilaspur (C.G.)

1.2 Extracts preparation: Air dried flower plant material $(50 \mathrm{~g})$ was extracted with ethanolic in a soxhlet apparatus for $10 \mathrm{hrs}$. The extract was concentrated under reduced pressure at $60^{\circ} \mathrm{C}$ using rotary evaporator. Then filtered, washed with about $25 \mathrm{ml}$ distilled water and dried and stored in the dark at $4^{0} \mathrm{C}$ for phytochemical analysis and antibacterial studies. 
1.3 Phytochemical analysis: The ethanolic extracts of flower of Moringa pterygosperma were analyzed by qualitative method for the presence of the alkaloids, saponins, flavonoids, steroids, phenol, glycoside and reducing sugars $(\mathbf{2 1}, \mathbf{2 2})$.

Table-1 Phytochemical screening of Moringa pterygosperma flowers of ethanolic extracts

\begin{tabular}{|l|c|}
\hline Test/ Extract & Ethanolic Extract \\
\hline Test for alkaloids & + \\
1. Mayer test & + \\
2. Wagner test & + \\
3.Dragendrorff test & + \\
\hline Test for flavonoids & + \\
1.Ferric chloride test & \\
2.Shinoda test & + \\
3.Lead acetate test & + \\
\hline Test for steroids & + \\
1.Salkowski's test & \\
2.Sulphur test & - \\
3.Liebermann Burchard's test & - \\
\hline Test for Saponins & + \\
1.Froth test & + \\
2.Foam test & + \\
\hline Test for glycoside & + \\
1.Legal's test & \\
2.Borntrager's test & \\
3.Baljet's test & + \\
4. Bromine water test & + \\
\hline Test for Carbohydrates & + \\
1.Molish test & + \\
2.Barfored's test & + \\
3.Benedic test & \\
4.Fehling test & \\
\hline Test for Tannins & + \\
1.Ferric chloride test & \\
2.Geletin test & + \\
\hline Test for Volatile oil & + \\
1 NaOH +HCl test & \\
\hline Test for Protein \& Amino acide & \\
1.Million reagent & \\
2.Ninhydrin reagent & + \\
3. Biuret test & + \\
4.Xanthoprotein test & + \\
\hline
\end{tabular}

$(+)$ : indicates presence or positive reaction

$(-)$ : indicates absence or Negative reaction

1.4 Micro organisms used: The organisms used were three gram positive (Micrococcus luteus, Staphylococcus aureus, Bacillus subtilis) and three gram negative (Escherichia coli, Pseudomonas aeruginosa and Vibrio cholera) bacteria.

1.5 Preparation of culture media: Nutrient broth was used for the preparation of inoculums of bacteria and Muller Hinton agar media (Hi- media) was used for preparation of medium for antibacterial screening.

1.6 Antibacterial activity index (AI): Antibacterial index (AI) for individual chemical extracts of Moringa pterygosperma was calculated as the mean value of the zone of inhibition obtained against all individual bacteria.

1.7 Determination of antibacterial activity: Antibacterial activity of the flower extracts was determined using agar well diffusion method by following the known procedure $(\mathbf{2 3}, \mathbf{2 4})$. After solidification of the medium at equal distance with the help of sterile metallic borer. The uniform volumes of different concentration of test and standard solution were added to the Petri dish and the solution were allowed to diffuse by leaving plates undisturbed for one hours at room temperature. The Petri dishes were incubated at $37^{\circ} \mathrm{C}$ for 24 hrs and the zone of inhibition were recorded in $\mathrm{mm}(\mathbf{2 5})$. The experiment was performed in triplicate and the average reading was recorded.

\section{Results and Discussion}

The qualitative phytochemical analysis of ethanolic extracts of flower part of Moringa pterygosperma showed the presence of active chemical constituent such as of alkaloids, flavonoids, steroids, glycoside, 
carbohydrates, proteins and amino acid while showed the absences of saponins, tannins, and volatile oil (table1)

Table-2 Antibacterial activity of crude ethanolic extracts of Moringa pterygosperma

\begin{tabular}{|l|c|c|c|c|c|c|c|}
\hline Extract & \multicolumn{9}{|c|}{ Diameter of zones of inhibition(mm) } & \multicolumn{3}{c|}{ Activity index } \\
\hline \multirow{3}{*}{ Flower } & Gram positive & Sa & Bs & Ec & Pa & Vc & \\
\cline { 2 - 8 } & Ml & 20 & 18 & 16 & 13 & 17 & 17.833 \\
\cline { 2 - 8 }
\end{tabular}

(Ml-Micrococcus luteus, Sa-Staphylococcus aureus, Bs-Bacillus subtilis, Ec-Eshcherichia coli, Pa-Psendomonas aeruginosa, Vc-vibrio cholera)

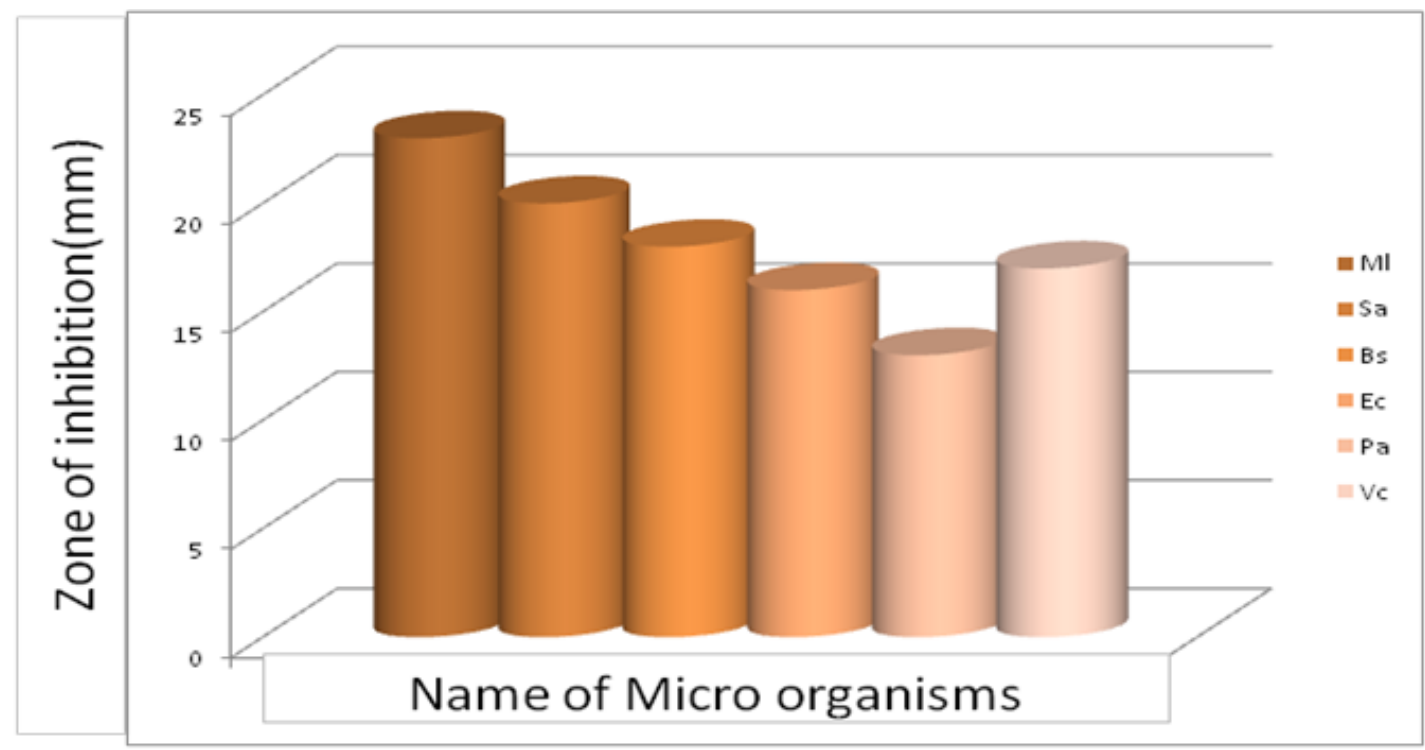

Antibacterial activity, ethanolic extracts showed varying degrees of inhibition on the tested organisms. All the gram positive bacteria such as Micrococcus luteus, Staphylococcus aureus, Bacillus subtilis and gram negative bacteria viz. Escherichia coli, Psendomonas aeruginosa, Vibrio cholera were found to be sensitive against the ethanolic extracts of floral part of Moringa pterygosperma, indicating the broad spectrum properties of the extracts. The antibacterial activity of ethanolic extracts of Moringa pterygosperma showed maximum zone of inhibition $(23 \mathrm{~mm})$ against Micrococcus luteus. Moreover, gram positive bacteria were found to be more sensitive than gram negative bacteria. Moringa pterygosperma flower extracts has the highest activity index (AI) value $17.833 \mathrm{~mm}$ highest antibacterial activity against the bacteria tested (table-2).

Findings of the present study suggested that ethanolic extracts of flower part of Moringa pterygosperma have high potential as antibacterial compounds against human pathogens and their ability to inhibit resistance action of bacteria could improve treatment. Thus this plant extracts could be used in the treatment of infection disease caused by resistant bacteria. Therefore the results laid down a basis for investigation the search of new active chemical constituents in Moringa pterygosperma responsible for antibacterial.

\section{References}

[1]. Aderogba, M.A., Okoh, E.K.and Idowu, T.O. “Journal of Biological Sciences”' 5, pp-239-242(2005).

[2]. Trapti Rastogi, Bhurda, V., Aswar, P.B. and khadabadi, S.S.”Asian J.Research Chem. Vol.2 (2). (2009).

[3]. Sentil Kumar, Reetha P.K.D. "J.Phytol. 1, pp -193-198 (2009).

[4]. Ali M.S., Azhar, I., Amtul, Z., Ahmad, V.U. and SSmanghni, K. "Fitoterapia, 70, pp-299-304 (1999).

[5]. Caceres, A. Cabera, O., Morales, O, Mollinedo, P. and Mendia, P. "J. of Ethano Pharmacology, 33, pp-213-216 (1991).

[6]. Grierson, D.S. and Afolayan, A.J. "Ethanopharmacol.3 (2), pp-58-62 (1999).

[7]. Anwar, F., Latif. S., Ashraf, M. And Gilan, A.H., Phytother. Res. 21, pp-17-25 (2007).

[8]. The wealth of India, Raw materials, Vol.VI, CSIR, New Delhi pp-426 (1962).

[9]. Parrota, J. “A Healing plants of peninsular Indian “, 53, CSBI, pp-528-529. (2001).

[10]. Caceres, A., Saravia, A., Rizzo, S. and Nave, F. “J. Ethanopharmacol. 36, pp 233-237(1992).

[11]. Lockett, C.T., Calvet, C.C., and Grivetti, L.E. "Int. J .Food Sci. Nutr. 51(3) pp-195-208(2000).

[12]. Giri, I.C., Shamin, Q.M.D., Safwan, A.K., Jitendra, P., Chaudhary, R. and Singh, A. "Int. J Pharma. Professionals Res.”, Vol.1, pp88 (2010).

[13]. Pal, S.K., Mukherjee, P.K. and Saha, B.P. "Phytother.Res. 9, pp 463-465(1995).

[14]. Mahajan. S.G., Banerjee, A., Chauhan, B.F. and Mehta A.A., Int. J. Toxicol. 28, pp.519-527 (2009).

[15]. Bajpai, M.Pande A. Tewari, S.K. Prakash D. “Int. J. Food. Sci. Nutr.”56. pp-287-291(2005).

[16]. Gilani, A.H., Aftab K. Suria, A. and Faizi S., "Phytother. Res. 8, pp-87-91 (1994).

[17]. Al-Awwadi, N., Azay, J.Auger, G. and Telssedre P.L., "J. Agric. Food Chem.” 52, pp. 1008-1016 (2004).

[18]. Panda, S.K., Thatoi, H.N.and Dutta S.K. "Journal of Medicinal plant research", 3(4) pp-294-300 (2009). 
[19]. Napolean. P, Anitha, J. and Emilin, R.R. “Current Biotica.” 3(1), pp-33-37(2009).

[20]. Talukdar, A.D., Choudhary, M.D., Chakraborty M. and Dutta, B.K. "Assam University Journal of Science and Technology ,Biological and Environmental Science", 5(1), pp-70-74(2010).

[21]. Horborne, J.B. "Phytochemical Method A Guide to modern technique of plant analysis", $3^{\text {rd }}$ end, New Delhi, Springer Pvt. Ltd. (2005).

[22]. Tiwari, P.Kaur M., Kaur G. and Kaur H. "Phytochemical Screening and Extraction A review", International Pharmasceutica Sciencia, Vol.I (1), pp-98-105(2011).

[23]. Valsaraj, R., Pushpangadan, P., Smith, U.W., Adersen, A. and Nyman U. Antimicrobial Screening of selected medicinal plants from India, Journal of Ethno pharmacology, pp-58, 75-83, (1997).

[24]. Grierson, D.S. and Afolayan, A.J. “J. Ethno pharmacol.” 3(2), pp.58-62 (1999). 